\title{
PENGEMBANGAN PEMBELAJARAN INKUIRI BERBANTUAN PhET UNTUK MELATIHKAN KETERAMPILAN PROSES SAINS SISWA
}

\author{
Teguh Budi Raharjo Eko Saputra ${ }^{1)}$ Mohamad Nur ${ }^{2)}$, Tarzan Purnomo ${ }^{3)}$ \\ ${ }^{1)}$ Program Studi Pendidikan Sains, Universitas Negeri Surabaya \\ 2) Dosen Program Studi Pendidikan Sains, Universitas Negeri Surabaya \\ 3) Dosen Jurusan Biologi FMIPA Universitas Negeri Surabaya
}

Email: dhiacomp23@gmail.com

\begin{abstract}
Abstrak: Penelitian ini bertujuan untuk menghasilkan perangkat pembelajaran IPA materi listrik dinamis menggunakan media KIT listrik yang dilengkapi PhET yang valid, praktis, dan efektif untuk melatihkan keterampilan proses sains siswa SMP. Penelitian dilaksanakan dengan menggunakan tiga tahap dari model 4-D, yaitu tahap pendefinisian (define), perancangan (design), pengembangan (develop) dan diujicobakan di kelas IX SMP Negeri 1 Kertek Wonosobo semester ganjil tahun pelajaran 2016/2017 dengan rancangan penelitian One Group PretestPosttest Design. Parameter penelitian yang diukur adalah validitas, kepraktisan, dan efektivitas perangkat pembelajaran. Pengumpulan data menggunakan metode observasi, angket, dan tes. Teknik analisis data menggunakan metode analisis deskriptif kuantitatif dan kualitatif. Hasil penelitian menunjukkan perangkat pembelajaran IPA menggunakan media KIT listrik yang dilengkapi PhET untuk materi listrik dinamis yang dikembangkan valid, praktis, dan efektif untuk melatihkan keterampilan proses sains siswa.
\end{abstract}

Kata Kunci: Kit listrik, perangkat pembelajaran, keterampilan proses sains, simulasi PhET

\section{PENDAHULUAN}

Pendidikan memegang peranan penting dalam menunjang kemajuan dan masa depan bangsa, tanpa pendidikan yang baik mustahil suatu bangsa akan maju. Berhasil atau tidaknya suatu pendidikan dalam suatu negara salah satunya adalah karena guru. Guru mempunyai peranan yang sangat penting dalam perkembangan dan kemajuan anak didiknya. Dari sinilah guru dituntut untuk dapat menjalankan tugas dengan sebaik-baiknya.

Pada Kurikulum Tingkat Satuan Pendidikan (KTSP), Ilmu Pengetahuan Alam (IPA) merupakan salah satu mata pelajaran wajib di sekolah. IPA merupakan mata pelajaran yang berhubungan dengan fenomena yang terjadi di alam. Dengan mempelajari seluk beluk alam dan fenomenanya, siswa diharapkan mampu memahami manfaat alam dalam kehidupan sehari-hari dan dapat memecahkan masalah yang dihadapi dalam menjalani kehidupannya. Secara umum IPA meliputi tiga bidang ilmu dasar, yaitu biologi, fisika, dan kimia. Fisika merupakan 
salah satu cabang IPA (sains) yang mendasari perkembangan teknologi maju dan konsep hidup harmonis dengan alam. Sesuai dengan tuntutan kurikulum KTSP pembelajaran IPA di SMP dilaksanakan secara terpadu, namun kenyataannya pembelajaran IPA masih dilakukan secara parsial (Dewi, 2012). IPA bertujuan agar siswa memiliki kemampuan antara lain mengembangkan pengalaman untuk dapat merumuskan masalah, mengajukan dan menguji hipotesis melalui percobaan, merancang instrumen percobaan, mengumpulkan, mengolah dan menafsirkan data serta mengkomunikasikan hasil percobaan secara lisan dan tertulis (BNSP, 2006).

Sudjana (2009) menyatakan hasil belajar adalah kemampuan-kemampuan yang dimiliki siswa setelah pengalaman belajarnya. Hasil belajar merupakan tujuan yang dirumuskan sebelum proses belajar mengajar dilaksanakan. Pada umumnya hasil belajar meliputi pengetahuan, sikap dan keterampilan. Hasil belajar akan diperoleh siswa setelah menempuh belajarnya atau proses belajar mengajar.

Ilmu Pengetahuan Alam (IPA) sebagai produk mengandung arti bahwa di dalam IPA terdapat fakta-fakta, hukum-hukum, prinsip-prinsip, dan teori-teori yang sudah diterima kebenarannya (BNSP, 2006). IPA sebagai proses atau metode berarti bahwa IPA merupakan suatu proses atau metode untuk mendapatkan pengetahuan. IPA tidak hanya mengutamakan hasil (produk), tetapi proses juga sangat penting dalam membangun pengetahuan siswa. Dalam hal ini berarti siswa perlu untuk diajak dan atau ikut terlibat dalam kegiatan laboratorium. Maka dari itu kegiatan laboratorium dalam pembelajaran IPA sangat penting, hal ini sesuai dengan Permendiknas No. 41 Tahun 2007 tentang Standar Proses, yaitu dalam pelaksanaan pembelajaran seharusnya guru memfasilitasi siswa melakukan percobaan di laboratorium.

Para ahli pendidikan memandang sains tidak hanya terdiri atas fakta, konsep dan teori yang dapat dihafalkan, tetapi juga terdiri atas kegiatan atau proses aktif menggunakan pikiran dan sikap ilmiah dalam mempelajari gejala alam yang belum dapat diterangkan. Ilmu Pengetahuan Alam sebagai ilmu yang terdiri dari produk dan proses. Produk IPA terdiri atas fakta, konsep, prinsip, prosedur, teori, hukum dan postulat. Semua itu merupakan produk yang diperoleh melalui serangkaian proses penemuan ilmiah melalui metode ilmiah yang didasari oleh sikap ilmiah (BNSP, 2006).

Keterampilan proses sains adalah keterampilan-keterampilan yang dipelajari siswa pada saat melakukan inkuiri ilmiah. Keterampilan proses sains adalah keterampilan yang dapat dilakukan siswa dalam kegiatan belajar mengajar, seperti pengamatan, pengklasifikasian, penginferensian, peramalan, pengkomunikasian, pengukuran, penggunaan bilangan, penginterpretasian data, melakukan eksperimen, pengontrolan variabel, perumusan hipotesis, pendefinisian secara operasional, dan perumusan model (Nur, 2011). Dengan demikian keterampilanketerampilan tersebut perlu dilatihkan pada siswa dalam pembelajaran IPA. Untuk membantu mempelajari sains yang luas, sains dikategorikan menjadi: biologi, 
yang mengkaji organisme hidup; ilmu kebumian, yang menyelidiki bumi dan ruang angkasa; atau ilmu fisik yang mengkaji materi dan energi. Fisika sebagai salah satu disiplin ilmu merupakan bagian IPA atau sains yang bertujuan untuk mempelajari fenomena-fenomena yang berhubungan dengan materi dan energi (Alonso, 1979). Fisika merupakan salah satu cabang IPA yang mendasari perkembangan teknologi maju dan konsep hidup harmonis dengan alam. Pengelolaan sumber daya alam dan lingkungan serta pengurangan dampak bencana alam tidak akan optimal tanpa pemahaman yang baik tentang fisika (Depdiknas, 2006).

Proses pembelajaran IPA sebaiknya diintegrasikan dengan kegiatan praktikum di laboratorium. Namun demikian, masih banyak sekolah yang tidak memiliki peralatan laboratorium terutama sekolah yang letaknya jauh dari kota. Hanya sekolah yang mempunyai anggaran besar yang mempunyai peralatan memadai, oleh karena itu diperlukan perhatian dan upaya kreatif dan inovatif guru mata pelajaran IPA, terutama hal penggunaan laboratorium dalam proses belajar mengajar. Hal ini sesuai teori kode ganda (Dual Code Theory) dari Paivio, yang menghipotesakan bahwa informasi tersimpan dalam memori jangka panjang dalam dua bentuk, yaitu visual dan verbal (Nur, 2004). Teori ini meramalkan bahwa informasi yang disajikan baik secara visual dan verbal diingat lebih baik daripada informasi yang hanya disajikan dengan salah satu cara.

Kegiatan laboratorium di sekolah kebanyakan belum mengangkat persoalan pemecahan masalah bagi siswa, tetapi hanya sekadar mengajak siswa memverifikasi fakta dari konsep yang telah disampaikan guru dalam pembelajaran. Dari segi materi pembelajaran, kegiatan pembelajaran yang terjadi lebih statis karena didominasi guru. Hal ini disebabkan kegiatan laboratorium yang dilakukan tidak mengajak siswa dihadapkan pada masalah yang harus dipecahkan, sehingga siswa benar-benar menemukan fakta, konsep, teori sebagai hasil temuannya sendiri. Kegiatan seperti ini akan terjadi bila pembelajaran dilakukan dengan berinkuiri.

Model pembelajaran inkuiri merupakan suatu rangkaian kegiatan belajar yang melibatkan secara maksimal seluruh kemampuan siswa untuk mencari dan menyelidiki secara sistematis, kritis, logis, analitis, dan dapat merumuskan sendiri penemuannya dengan penuh percaya diri (Gulo, 2002). Pembelajaran inkuiri menekankan kepada proses mencari dan menemukan. Pembelajaran inkuiri merupakan rangkaian kegiatan pembelajaran yang menekankan pada proses berpikir kritis dan analitis untuk mencari dan menemukan jawaban sendiri jawaban dari suatu masalah yang dipertanyakan (Hosnan, 2014).

Pengajaran berbasis inkuiri merupakan model pengajaran yang telah dikembangkan untuk tujuan mengajarkan siswa cara berpikir (Arends, 2013). Pembelajaran inkuiri dirancang untuk mengajak siswa secara langsung ke dalam proses ilmiah. Sasaran utama kegiatan pembelajaran inkuiri adalah: (1) melibatkan siswa secara maksimal dalam proses kegiatan belajar; (2) keterarahan kegiatan secara logis dan sistematis pada tujuan pembelajaran; 
mengembangkan sikap percaya pada diri siswa tentang apa yang ditemukan dalam proses inkuiri.

Hasil penelitian Potale (2004) menyatakan bahwa pembelajaran dengan mengembangkan inkuiri siswa dapat digunakan untuk melatihkan keterampilan proses sains. Lebih lanjut Potale menyatakan bahwa perangkat pembelajaran dengan mengembangkan inkuiri siswa dapat meningkatkan hasil belajar siswa. Hasil penelitian Ruddinnillah (2011) menyatakan bahwa buku siswa dan lembar kerja siswa inovatif fisika dikembangkan dengan pendekatan inkuiri efektif untuk melatihkan keterampilan proses kepada siswa SMK. Berdasarkan hasil-hasil penelitian tersebut, semakin meyakinkan bahwa pembelajaran berbasis inkuiri dapat diterapkan untuk melatihkan keterampilan proses sains siswa.

Kenyataan sekarang ini merupakan suatu masalah dan tantangan bagi seorang guru atau pengajar untuk meningkatkan hasil belajar siswa pada mata pelajaran IPA. Salah satu penentu di antaranya adalah dengan menggunakan media pembelajaran selama proses pembelajaran berlangsung. Peranan media dalam proses belajar mengajar menurut Gerlach dan Ely (dalam Sadiman, 2008) adalah: (1) menangkap, menyimpan dan menampilkan kembali suatu objek atau kejadian. (2) menampilkan kembali objek atau kejadian dengan berbagai macam cara disesuaikan dengan keperluan. (3) menampilkan sesuatu objek atau kejadian yang mengandung makna.

Ibrahim (2010) mengemukakan fungsi atau peranan media dalam proses belajar mengajar, antara lain: (1) dapat menghindari terjadinya verbalisme. (2) membangkitkan minat atau motivasi. (3) menarik perhatian. (4) mengatasi keterbatasan ruang, waktu dan ukuran. (5) mengaktifkan siswa dalam belajar. (6) mengefektifkan pemberian rangsangan untuk belajar.

Dalam upaya memperbaiki proses pembelajaran agar efektif dan fungsional, maka fungsi media pembelajaran sangat penting untuk dimanfaatkan. Pemakaian media dalam proses pembelajaran dimaksudkan untuk mempertinggi daya cerna siswa terhadap informasi atau materi pembelajaran yang diberikan.

Seiring dengan perkembangan teknologi informasi dewasa ini, para ahli berupaya mengembangkan berbagai media pembelajaran berbasis komputer. Ada yang berupa buku elektronik (ebook), video animasi, video interaktif, slide powerpoint, berbagai program flash hingga laboratorium virtual. Semua jenis media itu sangat membantu guru dalam menyampaikan informasi kepada siswa selama proses belajar mengajar, karena penerapan media yang baik akan meningkatkan keberhasilan belajar siswa.

Media laboratorium virtual adalah satu bentuk laboratorium dengan kegiatan pengamatan atau eksperimen dengan menggunakan software yang dijalankan oleh sebuah komputer, semua peralatan yang diperlukan oleh sebuah laboratorium terdapat di dalam software tersebut. Laboratorium virtual memiliki beberapa keunggulan. Keunggulan-keunggulan itu antara lain adalah bisa menjelaskan konsep abstrak yang tidak bisa dijelaskan melalui penyampaian secara verbal. 
Laboratorium virtual bisa menjadi tempat melakukan eksperimen yang tidak bisa dilakukan di dalam laboratorium konvensional.

PhET simulation interaktif Colorado merupakan media simulasi interaktif yang menyenangkan dan berbasis penemuan (research based). PhET merupakan ciptaan komunitas Sains melalui PhET Project di University of Colorado. Software ini dapat digunakan untuk memperjelas konsep dan simulasi eskperimen.

Pemanfaatan komputer sebagai sebuah sarana pengembangan pendidikan saat ini sudah menjadi suatu kebutuhan utama. Komputer dalam pembelajaran fisika dapat digunakan sebagai alat bantu percobaan, simulasi, demonstrasi, dan alat hitung. Dalam penelitian ini, simulasi yang digunakan berupa simulasi $\mathrm{PhET}$.

PhET simulation ini dipilih karena simulasi ini berbasis program java yang memiliki kelebihan. Easy java simulation (ejs) dirancang khusus untuk memudahkan tugas para guru dalam membuat simulasi IPA dengan memanfaatkan komputer sesuai dengan bidang ilmunya. Semua simulasi PhET didapatkan secara gratis di situs https://phet.colorado.edu/in. PhET mudah digunakan dan diaplikasikan di dalam kelas.

Untuk melengkapi media PhET tersebut, maka salah satu usaha yang bisa dilakukan adalah mengembangkan media pembelajaran interaktif. Salah satu bentuk media pembelajaran itu adalah media KIT listrik. Pengetahuan IPA terdiri atas konsep dan prinsip yang pada umumnya susah dimengerti siswa, oleh karena itu untuk memberi pemahaman siswa, guru dalam mengajar harus menggunakan media pembelajaran. Pembelajaran berorientasi pada siswa di mana melibatkan siswa secara langsung sangat diharapkan baik dengan menggunakan PhET maupun KIT listrik sehingga terjadi peningkatan hasil belajar siswa, selain itu siswa dapat membuktikan kebenaran apa yang telah dipelajari secara teori.

Hasil penelitian Samsuri (2010) menyatakan bahwa pembelajaran fisika SMA pokok bahasan listrik dinamis menggunakan media simulasi PhET dan KIT sederhana dapat berjalan efektif, di mana siswa secara umum tertarik terhadap konten, media, dan metode/model pembelajarannya. Demikian pula hasil penelitian Sugiono (2011) menyatakan bahwa proses belajar mengajar menggunakan perangkat pembelajaran fisika yang dikembangkan multimedia PhET dan KIT sederhana untuk SMA dalam pokok bahasan alat-alat optik adalah efektif, di mana saat kegiatan belajar mengajar berlangsung aktivitas siswa didominasi oleh kegiatan yang dicirikan keterampilan proses dan hasil kooperatif.

Untuk menentukan kualitas hasil pengembangan model dan perangkat pembelajaran diperlukan tiga kriteria: kevalidan, kepraktisan, dan keefektifan. Ketiga kriteria ini mengacu pada kriteria kualitas hasil penelitian pengembangan yang dikemukakan oleh Van Den Akker (1999) dan kriteria kualitas produk yang dikemukakan oleh Nieveen (2007).

Validitas dalam penelitian pengembangan meliputi validitas isi dan validitas konstruk. Validitas mengacu pada sejauh mana desain intervensi yang digunakan dalam penelitian ini, yaitu perangkat pembelajaran menggunakan media KIT listrik yang dilengkapi PhET materi listrik dinamis untuk melatihkan 
keterampilan proses sains yang didasarkan pada pengetahuan state-of-the art atau kemutakhiran (validitas isi) dan berbagai komponen dari perangkat pembelajaran menggunakan media KIT listrik yang dilengkapi PhET berhubungan satu dengan yang lain (validitas konstruk). Menurut Nieveen (2007) aspek validitas dapat dilihat dari: (1) apakah kurikulum atau perangkat pembelajaran yang dikembangkan berdasar pada state-of-the art pengetahuan; dan (2) apakah berbagai komponen dari perangkat pembelajaran terkait secara konsisten antara yang satu dengan lainnya. Aspek kepraktisan dilihat dari segi pengguna: (1) apakah para ahli dan praktisi berpendapat bahwa apa yang dikembangkan dapat digunakan dalam kondisi normal; dan (2) apakah kenyataan menunjukkan bahwa apa yang dikembangkan tersebut dapat diterapkan oleh guru dan siswa. Dan aspek keefektifan juga dikaitkan dengan dua hal, yaitu: (1) ahli dan praktisi berdasarkan pengalamannya menyatakan bahwa produk tersebut efektif, (2) dalam operasionalnya model tersebut memberikan hasil yang sesuai dengan harapan.

Dalam penelitian pengembangan pembelajaran, indikator untuk menyatakan bahwa keterlaksanaan model dikatakan efektif, dapat dilihat dari komponenkomponen: (1) aktivitas siswa (2) respon siswa dan (3) hasil belajar siswa. Hal ini berdasarkan pada tingkatan pengalaman dan hasil intervensi konsisten dengan tujuan yang dimaksud. Tingkatan pengalaman ini dengan adanya respon positif dari siswa yang ditunjukkan melalui angket yang diberikan sedangkan intervensi konsisten dengan tujuan yang dimaksud ditunjukkan dengan tes hasil belajar siswa. Sehingga, media pembelajaran ini dikatakan efektif jika memberikan hasil yang sesuai harapan dengan ditunjukkan oleh keaktifan siswa, respon siswa dan hasil belajar siswa yang berupa hasil belajar produk, keterampilan proses sains dan psikomotor siswa.

Model pembelajaran adalah kerangka konseptual atau operasional, yang melukiskan prosedur yang sistematis dalam mengorganisasikan pengalaman belajar untuk mencapai tujuan belajar tertentu dan berfungsi sebagai pedoman bagi para pengajar dalam merencanakan, dan melaksanakan aktifitas pembelajaran (Hosnan, 2014). Guna mencapai hasil belajar siswa di sekolah yang maksimal dan memadai, diperlukan kreatifitas guru dalam menjalankan proses pembelajarannya. Kreatifitas guru dapat menjadi entry point dalam upaya meningkatkan pencapaian hasil belajar siswa. Kreatifitas guru yang dimaksud adalah kemampuan guru dalam meninggalkan gagasan, ide, dan hal yang dinilai mapan, rutinitas, usang dan beralih untuk menghasilkan atau memunculkan gagasan, ide, dan hal yang baru, kreatif dan menarik.

Inkuiri didefinisikan oleh Piaget sebagai pembelajaran yang mempersiapkan situasi bagi siswa untuk melakukan eksperimen sendiri, dalam arti luas ingin melihat apa yang terjadi, ingin melakukan sesuatu, ingin menggunakan simbolsimbol dan mencari jawaban atas pertanyaan sendiri, menghubungkan penemuan yang satu dengan penemuan yang lain, membandingkan apa yang ditemukan dengan yang ditemukan orang lain. Inkuiri diawali dengan kegiatan pengamatan 
dalam rangka untuk memahami suatu konsep. Siklus yang terdiri dari kegiatan mengamati, bertanya, menyelidiki, menganalisis, dan merumuskan teori, baik secara individu maupun bersama-sama dengan teman lainnya. Proses ini sekaligus terjadi aktifitas mengembangkan dan menggunakan keterampilan berpikir kritis (Ibrahim, 2010). Secara umum model inkuiri adalah strategi mengajar yang dirancang untuk membimbing siswa bagaimana meneliti masalah dan pertanyaan berdasarkan fakta.

Ada lima tahapan dalam pembelajaran inkuiri (Kardi, 2012) yaitu: (1) Mengidentifikasi pertanyaan atau masalah. (2) Merumuskan hipotesis. (3) Mengumpulkan data. (4) Menganalisa data. (5) Merumuskan generalisasi. Sedangkan menurut Hosnan (2014), ada enam tahapan dalam pembelajaran inkuiri, yaitu: (1) Orientasi. (2) Merumuskan masalah. (3) Merumuskan hipotesis. (4) Mengumpulkan data. (5) Menguji hipotesis. (6) Merumuskan kesimpulan.

Pembelajaran inkuiri merupakan pembelajaran yang banyak dianjurkan, karena model pembelajaran ini memiliki beberapa kelebihan sebagai berikut: (1) Pembelajaran inkuiri menekankan kepada pengembangan aspek kognitif, afektif, dan psikomotorik secara seimbang, sehingga pembelajaran inkuiri dianggap lebih bermakna. (2) Pembelajaran inkuiri dapat memberikan ruang kepada siswa untuk belajar sesuai dengan gaya belajar mereka. (3) Inkuiri merupakan model pembelajaran yang dianggap sesuai dengan perkembangan psikologi belajar modern yang menganggap belajar adalah proses perubahan tingkah laku berkat adanya pengalaman. (4) Pembelajaran ini dapat melayani kebutuhan siswa yang memiliki kemampuan di atas rata-rata. Artinya siswa yang memiliki kemampuan belajar bagus tidak akan terhambat oleh siswa yang lemah dalam belajar (Arends, 2013).

Di samping memiliki kelebihan, pembelajaran inkuiri juga mempunyai kekurangan, di antaranya sebagai berikut: (1) Jika strategi ini digunakan sebagai pembelajaran, maka akan sulit mengontrol kegiatan dan keberhasilan siswa. (2) Pembelajaran inkuiri sulit dalam merencanakan pembelajaran karena terbentur dengan kebiasaan siswa dalam belajar. (4) Kadang-kadang dalam mengimplementasikannya memerlukan waktu yang panjang sehingga sering pendidik sulit menyesuaikannya dengan waktu yang telah ditentukan. (5) Selama kriteria keberhasilan belajar ditentukan oleh kemampuan siswa menguasai materi pelajaran, maka pembelajaran inkuiri ini akan sulit diimplementasikan oleh siswa (Arends, 2013).

\section{METODE}

Penelitian ini merupakan disain riset pendidikan/ educational design research (Nieveen, 2007). Disain riset pendidikan dalam penelitian ini dengan mengembangkan perangkat pembelajaran menggunakan media KIT listrik yang dilengkapi PhET materi listrik dinamis IPA SMP berbasis inkuiri untuk melatihkan keterampilan proses sains siswa. Perangkat pembelajaran yang akan 
dikembangkan adalah Silabus, RPP, LKS, Lembar Penilaian Hasil Belajar, dan instrumen penelitian.

Rancangan penelitian ini menggunakan one group pretest-posttest design. Subjek penelitian ini adalah perangkat pembelajaran yang dikembangkan dan diujicobakan kepada siswa SMP. Perangkat pembelajaran dikembangkan menggunakan model 4-D. Menurut Thiagarajan (1974), proses pengembangan perangkat model ini terdiri dari empat tahap, yaitu tahap pendefinisian (define), perancangan (design), pengembangan (develop), dan penyebaran (disseminate). Pengembangan perangkat pada Penelitian ini juga mengacu Nieveen (2007), yang mengatakan desain riset terdiri 3 tahap atau fase, yaitu: fase penelitian pendahuluan, fase prototipe dan fase penilaian.

Teknik pengumpulan data yang digunakan dalam penelitian ini adalah (1) validasi perangkat oleh validator, (2) observasi, (3) angket respon siswa, dan (4) tes hasil belajar siswa. Instrumen yang dikembangkan oleh peneliti berupa lembar validasi perangkat, lembar pengamatan keterlaksanaan RPP, lembar keterbacaan LKS, lembar angket respon siswa, lembar aktivitas siswa, analisis hasil belajar siswa, dan lembar pengamatan kendala-kendala yang dihadapi selama proses pembelajaran. Teknik analisis data yang digunakan peneliti dalam penelitian ini adalah analisis dekriptif.

\section{HASIL DAN PEMBAHASAN}

a. Validitas Perangkat Pembelajaran

Hasil penelitian menunjukkan bahwa perangkat pembelajaran yang dikembangkan oleh peneliti layak untuk digunakan dalam pembelajaran. Kelayakan perangkat pembelajaran dapat dilihat berdasarkan hasil validitas perangkat yang mendapat kategori sangat valid (seperti yang ditunjukkan pada Tabel 1.1)

Tabel 1.1 Validitas Perangkat Pembelajaran

\begin{tabular}{|l|c|c|}
\hline \multirow{2}{*}{\multicolumn{1}{|c|}{ Perangkat Pembelajaran }} & \multicolumn{2}{c|}{ Hasil Validasi } \\
\cline { 2 - 3 } & Rata-rata & Keterangan \\
\hline Silabus & 3,66 & $\mathrm{SV}$ \\
\hline RPP & 3,78 & $\mathrm{SV}$ \\
\hline LKS KIT Listrik & 3,71 & $\mathrm{SV}$ \\
\hline LKS Siimulasi PhET & 3,69 & $\mathrm{SV}$ \\
\hline LP 2.1. Kognitif Produk & 3,61 & $\mathrm{SV}$ \\
\hline LP 2.2. Kognitif Proses & 3,59 & $\mathrm{~V}$ \\
\hline
\end{tabular}




\begin{tabular}{|l|c|c|}
\hline \multirow{2}{*}{ Perangkat Pembelajaran } & \multicolumn{2}{|c|}{ Hasil Validasi } \\
\cline { 2 - 3 } & Rata-rata & Keterangan \\
\hline LP 3.1. Psikomotor KIT Listrik & 3,62 & SV \\
\hline LP 3.2. Psikomotor Simulasi PhET & 3,62 & $\mathrm{SV}$ \\
\hline Pretest dan Posttest Kognitif Produk & 3,60 & $\mathrm{SV}$ \\
\hline Pretest dan Posttest Kognitif Proses & 3,61 & $\mathrm{SV}$ \\
\hline Pretest dan Posttest LP 3 Psikomotor & 3,61 & $\mathrm{SV}$ \\
\hline
\end{tabular}

\section{b. Hasil Belajar Siswa}

Hasil belajar yang dicapai siswa diukur setelah mengikuti proses pembelajaran pada Uji Coba I dan Uji Coba II meliputi tes hasil belajar kognitif produk, kognitif proses, dan psikomotor siswa. Tes hasil belajar tersebut diberikan kepada siswa berupa pretest dan posttest. Pretest diberikan sebelum pembelajaran dimulai untuk mengetahui keterampilan proses sains. Posttest diberikan setelah pembelajaran untuk mengetahui keterampilan proses sains dengan model pembelajaran inkuiri

Kelas IX G merupakan kelas penelitian $\left(\mathrm{X}_{1}\right)$ pada Uji Coba I, yaitu kelas pembelajaran yang dilaksanakan oleh peneliti dengan menerapkan perangkat pembelajaran menggunakan media KIT Listrik yang dilengkapi PhET materi listrik dinamis untuk melatihkan keterampilan proses sains. Kelas IX G sebagai kelas penelitian pada Uji Coba I ini, sebelum pembelajaran diberikan pretest $\left(\mathrm{O}_{1}\right)$ untuk mengetahui keterampilan awal proses sains terhadap materi listrik dinamis, menggunakan instrumen keterampilan proses sains dan diberikan posttest $\left(\mathrm{O}_{2}\right)$ pada akhir pembelajaran.

Kelas IX H merupakan kelas penelitian $\left(\mathrm{X}_{1}\right)$ pada Uji Coba II, yaitu kelas pembelajaran yang dilaksanakan oleh peneliti dengan menerapkan perangkat pembelajaran menggunakan media KIT Listrik yang dilengkapi PhET materi listrik dinamis untuk melatihkan keterampilan proses sains. Kelas IX H sebagai kelas penelitian pada Uji Coba II ini, sebelum pembelajaran diberikan pretest $\left(\mathrm{O}_{3}\right)$ untuk mengetahui keterampilan awal proses sains terhadap materi listrik dinamis, menggunakan instrumen keterampilan proses sains dan diberikan posttest $\left(\mathrm{O}_{4}\right)$ pada akhir pembelajaran.

Data hasil tes hasil belajar kognitif produk, kognitif proses, dan psikomotor siswa yang berupa pretest dan posttest selanjutnya diolah untuk menghitung sensitivitas, ketuntasan indikator soal, ketuntasan individu, ketuntasan klasikal dan N-Gain, dengan hasil sebagai berikut. 
Tabel 1.2 Ketuntasan Individu, Ketuntasan Klasikal dan $\mathrm{N}$-gain Tes Hasil Belajar Kognitif Produk pada Uji Coba I

\begin{tabular}{|l|c|c|c|c|}
\hline \multirow{2}{*}{\multicolumn{1}{|c|}{ Keterangan }} & \multicolumn{4}{|c|}{ Uji Coba I (IX G) } \\
\cline { 2 - 4 } & Pretes & Postes & N-Gain & Keterangan \\
\hline Rata-Rata & 32,07 & 86,21 & & \\
\hline Jumlah Tuntas & 1 & 26 & \multirow{2}{*}{0,78} & \multirow{2}{*}{ Tinggi } \\
\hline Ketuntasan Klasikal & $3,45 \%$ & $89,66 \%$ & & \\
\hline
\end{tabular}

Tabel 1.3 Ketuntasan Individu, Ketuntasan Klasikal dan $\mathrm{N}$-gain Tes Hasil Belajar Kognitif Produk pada Uji Coba II

\begin{tabular}{|l|c|c|c|c|}
\hline \multirow{2}{*}{ Keterangan } & \multicolumn{4}{|c|}{ Uji Coba II (IX H) } \\
\cline { 2 - 4 } & Pretes & Postes & N-Gain & Keterangan \\
\hline Rata-Rata & 61,25 & 95,63 & & \multirow{2}{*}{0,92} \\
Jumlah Tuntas & 12 & 32 & Tinggi \\
\hline Ketuntasan Klasikal & $37,50 \%$ & $100 \%$ & & \\
\hline
\end{tabular}

Tabel 1.4 Ketuntasan Individu, Ketuntasan Klasikal dan $\mathrm{N}$-gain Tes Hasil Belajar Kognitif Proses pada Uji Coba I

\begin{tabular}{|l|c|c|c|c|}
\hline \multirow{2}{*}{\multicolumn{1}{|c|}{ Keterangan }} & \multicolumn{4}{|c|}{ Uji Coba I (IX G) } \\
\cline { 2 - 3 } & Pretes & Postes & N-Gain & Ket. \\
\hline Rata-Rata & 0 & 96,28 & & \multirow{2}{*}{0,96} \\
\hline Jumlah Tuntas & 0 & 29 & \multirow{2}{*}{ Tinggi } \\
\hline Ketuntasan Klasikal & $0 \%$ & $100 \%$ & & \\
\hline
\end{tabular}

Tabel 1.4 Ketuntasan Individu, Ketuntasan Klasikal dan $N$-gain Tes Hasil Belajar Kognitif Proses pada Uji Coba II

\begin{tabular}{|c|c|c|c|c|}
\hline \multirow{2}{*}{ Keterangan } & \multicolumn{4}{|c|}{ Uji Coba II (IX H) } \\
\cline { 2 - 3 } & Pretes & Postes & N-Gain & Ket. \\
\hline Rata-Rata & 0 & 98,47 & & \multirow{2}{*}{ Tinggi } \\
\hline Jumlah Tuntas & 0 & 32 & 0,98 & \\
\hline Ketuntasan Klasikal & $0 \%$ & $100 \%$ & & \\
\hline
\end{tabular}

Berdasarkan Tabel Ketuntasan Individu, Ketuntasan Klasikal dan N-gain Tes Hasil Belajar Kognitif Produk pada Uji Coba I dan Uji Coba II pada penilaian siswa di atas, ketuntasan individu pada pretest Uji Coba I dan Uji Coba II hasil belajar kognitif proses tidak ada siswa yang tuntas, dan ketuntasan klasikalnya 0 $\%$. Sedangkan ketuntasan individu pada posttest Uji Coba I dan Uji Coba II hasil belajar kognitif proses seluruh siswa yang dinyatakan tuntas, dan ketuntasan klasikalnya $100 \%$. Seluruh siswa mengalami peningkatan hasil belajar kognitif proses dengan rata - rata skor $N$-gain 0,96 (Uji Coba I) dan 0,98 (Uji Coba II) dengan kategori tinggi. 
Berdasarkan Tabel 1.5 dan 1.6 Ketuntasan Individu, Ketuntasan Klasikal dan $N$-gain Tes Hasil Belajar Psikomotor pada Uji Coba I dan Uji Coba II pada penilaian siswa di atas, ketuntasan individu pada pretest Uji Coba I dan Uji Coba II hasil belajar psikomotor tidak ada siswa yang tuntas, dan ketuntasan klasikalnya 0\%. Sedangkan ketuntasan individu pada posttest Uji Coba I dan Uji Coba II hasil belajar psikomotor seluruh siswa yang dinyatakan tuntas, dan ketuntasan klasikalnya $100 \%$. Seluruh siswa mengalami peningkatan hasil belajar psikomotor dengan rata - rata skor $N$-gain 0,98 (Uji Coba I) dan 0,99 (Uji Coba II) dengan kategori tinggi.

Tabel 1.5 Ketuntasan Individu, Ketuntasan Klasikal dan N-gain Tes Hasil Belajar Psikomotor pada Uji Coba I

\begin{tabular}{|c|c|c|c|c|}
\hline \multirow{2}{*}{ Keterangan } & \multicolumn{4}{|c|}{ Uji Coba I (IX G) } \\
\cline { 2 - 3 } & Pretes & Postes & N-Gain & Keterangan \\
\hline Rata-Rata & 0 & 98,14 & & \multirow{2}{*}{0,98} \\
\hline Jumlah Tuntas & 0 & 29 & Tinggi \\
\hline Ketuntasan Klasikal & $0 \%$ & $100 \%$ & & \\
\hline
\end{tabular}

Tabel 1.6 Ketuntasan Individu, Ketuntasan Klasikal dan $N$-gain Tes Hasil Belajar Psikomotor pada Uji Coba II

\begin{tabular}{|c|c|c|c|c|}
\hline \multirow{2}{*}{ Keterangan } & \multicolumn{4}{|c|}{ Uji Coba II (IX H) } \\
\cline { 2 - 3 } & Pretes & Postes & N-Gain & Keterangan \\
\hline Rata-Rata & 0 & 98,91 & & \\
\hline Jumlah Tuntas & 0 & 32 & 0,99 & Tinggi \\
\hline Ketuntasan Klasikal & $0 \%$ & $100 \%$ & & \\
\hline
\end{tabular}

\section{PENUTUP}

Berdasarkan temuan penelitian dan hasil penelitian, maka dapat dibuat kesimpulan bahwa disain riset perangkat pembelajaran listrik dinamis IPA SMP menggunakan media KIT Listrik yang dilengkapi PhET dinyatakan valid, praktis, efektif dan dapat digunakan dalam pembelajaran IPA untuk melatihkan keterampilan proses sains siswa.Penggunaan perangkat pembelajaran inkuiri dengan simulasi PhET yang dikembangkan ini dalam pembelajaran di kelas memerlukan waktu yang lama dibanding metode tradisional, maka sebelum menggunakan simulasi PhET diperlukan pengenalan tentang simulasi PhET terlebih dahulu diluar jam pelajaran agar pembelajaran berlangsung baik.Perangkat pembelajaran inkuiri dengan simulasi PhET untuk melatihkan kemampuan proses sains siswa ini dapat dijadikan sebagai salah satu referensi dalam menerapkan Kurikulum 2013 yang mulai tahun 2016 semua SMP sebagian besar diwajibkan menerapkan Kurikulum 2013. 


\section{REFERENSI}

Alonso, E. F. (1979). Fundamental University Physics. New York: Addison Wesley.

Arends, R. I. (2013). Belajar Untuk Mengajar (Learning to Teach). Jakarta: Salemba Humanika.

BNSP. (2006). Model Pembelajaran Terpadu IPA. Jakarta: BNSP.

Depdiknas. (2006). Permendiknas No 22 Tahun 2006 Tentang Standar Isi Satuan Pendidikan Dasar dan Menengah. Jakarta: BSNP.

Depdiknas. (2007). Permendiknas No 41 Tahun 2007 Tentang Standar Proses. Jakarta: BNSP.

Dewi. (2013). Pengembangan Perangkat Pembelajaran IPA Terpadu dengan Setting Inkuiri Terbimbing untuk Meningkatkan Pemahaman Konsep dan Kinerja Ilmiah Siswa. Jurnal Program Studi Pendidikan IPA Pascasarjana Universitas Pendidikan Ganesha,3, 1-11.

Gulo, W. (2002). Strategi Belajar Mengajar. Jakarta: Gramedia Widia Sarana Indonesia.

Hosnan, M. (2014). Pendekatan Saintifik dan Kontekstual Dalam Pembelajaran Abad 21. Bogor: Ghalia Indonesia.

Ibrahim, M. (2010). Dasar-dasar Proses Belajar Mengajar. Surabaya: University Press, UNESA.

Kardi, S. (2012). Pengantar Pengembangan Kurikulum dan RPP. Surabaya: PPs UNESA.

Nieveen, T. P. (2007). An Introduction to Educational Design Research. Shanghai: SLO-Netherlands Institute for Curiculum Development, 94.

Nur, M. (2004). Teori-Teori Perkembangan Kognitif. Surabaya: Pusat Sains dan Matematika Sekolah Universitas Negeri Surabaya.

Nur, M. (2011). Modul Keterampilan-Keterampilan Proses Sains. Surabaya: Pusat Sains dan Matematika Sekolah Universitas Negeri Surabaya.

Potale, M. (2004). Mengembangkan Inkuiri Siswa untuk Melatihkan Keterampilan Dasar Sains Bahan Kajian Tekanan di SLTP Negeri 21 Surabaya. Tesis. Program Studi Pendidikan Sains Program Pascasarjana UNESA: Tidak diterbitkan

Ruddinnillah, A. (2011). Pengembangan Buku Siswa dn LKS Inovatif Fisika dengan Pendekatan Inkuiri untuk Melatihkan Keterampilan Proses Siswa Kelas X SMK. Tesis. Program Studi Pendidikan Sains Program Pascasarjana UNESA: Tidak diterbitkan

Sadiman, A. S. (2008). Media Pendidikan. Jakarta: PT Grafindo Persada.

Samsuri. (2010). Pengembangan Perangkat Pembelajaran Berbasis Media Simulasi PhET daan KIT Sederhana Pada Pembelajaran Fisika SMA Pokok Bahasan Listrik Dinamis. Tesis. Program Studi Pendidikan Sains Program Pascasarjana UNESA: Tidak diterbitkan

Sudjana, N. (2009). Penilaian Hasil Proses Belajar Mengajar. Bandung: Rosdakarya 